\title{
Synthesis of Co-Al-Cl LDH by Cathodic Material Reprocessing from Cellular Phone Batteries
}

\author{
Fábio Augusto do Amaral*, Érica Oliveira Machado, Leonardo Luis de Freitas,
}

\author{
Laiane Kálita Santana, Sheila Cristina Canobre
}

\begin{abstract}
Laboratório de Armazenamento de Energia e Tratamento de Efluentes - LAETE, Instituto de Química, Universidade Federal de Uberlândia - UFU, Av. João Naves de Ávila, 2121, CEP 38408-100, Uberlândia, MG, Brasil
\end{abstract}

Received: June 18, 2013; Revised: January 15, 2014

\begin{abstract}
The aim of this paper was the recovering of the cathodic material from discarded lithium ion batteries for obtainment of the lamellar double hydroxides (LDHs) by the co-precipitation method at variable $\mathrm{pH}$ in $\mathrm{HCl}$ and $\mathrm{H}_{2} \mathrm{O}_{2}$ 1:1 (v/v) acid solution containing $\mathrm{Co}$ and $\mathrm{Al}$ (extracted from cathodic material composed of $\mathrm{LiCoO}_{2}$ and aluminum foil). These metals were precipitated in $\mathrm{LiOH}$ at $\mathrm{pH} 9$ or 11 , or $\mathrm{NH}_{4} \mathrm{OH}$ at $\mathrm{pH} 9$ and submitted to the hydrothermal treatment (HT) to improve the structural organization of the LDHs lamellae. After precipitation, the resulting solids were structurally characterized by XRD for phase identification and calculation of the unit cell parameter, thermally by TGA for the identification of the mass loss and morphologically by SEM. The sample obtained by precipitation with $\mathrm{LiOH}$ at $\mathrm{pH} 11$ / hydrothermal treatment showed diffraction peaks similar to hydrotalcite, morphological and thermal characteristics similar to the pattern Co-Al-Cl LDH obtained by co-precipitation at constant $\mathrm{pH} 8$.
\end{abstract}

Keywords: lithium ion batteries, $\mathrm{LiCoO}_{2}$ and aluminum foil recovering, reprocessing of cellular phone battery and lamellar double hydroxides

\section{Introduction}

In the last few years the technological advances and the equipment production with portable power supply, which occupy the minimum space possible, last long and that are mainly rechargeable, drawing interest of the population in purchasing electronic products. Notebooks, i-pods, tablets, cellular phones, and digital machines are the most desirable devices. They use lithium ion batteries made up of lithiated graphite $\left(\mathrm{LiC}_{6}\right)$ as anode, lithium cobaltate $\left(\mathrm{LiCoO}_{2}\right)$ or lithium manganate $\left(\mathrm{LiMn}_{2} \mathrm{O}_{4}\right)$ as cathodes and an organic electrolyte containing lithium salt $\left(\mathrm{LiPF}_{6}\right.$ or $\left.\mathrm{LiClO}_{4}\right)$ in ethylene or dimethylene carbonates (EC/DMC). $\mathrm{LiCoO}_{2}$ is frequently used due to its high charge density, long life cycles and extremely low auto-discharge charge, however, its production is highly costly and the cobalt reserves are limited ${ }^{1}$. Although cobalt is one of the most abundant elements, it can be obtained mainly as a co-product of the copper and nickel mining. The Cobalt is part of a short list chosen as strategic metal for the economy of a country and for their critical limitations of reservation and extraction forms. On the other hand, like all human activity, these lithium ion batteries generate environmental problems due to their incorrect disposal, which is supported by legislation outdated or inadequate supervision. The rapid technological advancement of the portable electronics has emerged as a problematic disposal of appliances "old-fashioned" devices and their batteries, many batteries are constituted by lithium ion. Most of the time, this disposal is not made of proper locations which causes contamination and environmental degradation due to the battery metals. World lithium ion

*e-mail: fabioamaral@yahoo.com.br, fabioamaral@iqufu.ufu.br batteries (LIBs) production reached 500 million units in 2000 and it is expected to reach 4.6 billion in $2010^{[2-5]}$ Brazil is a cobalt producer, but only in 2010, metal oxides and hydroxides 2401 tonnes were imported generating an expense of approximately $\$ 15.4$ million $^{[6]}$. The high demand and cobalt value associated with environmental damage can reach the human health, directly or indirectly. Thus, it can consider the $\mathrm{LiCoO}_{2}$ recycling a plausible alternative for solving these problems. Since LIBs are substitutes for other secondary batteries due to lightness and good performance, the disposal of these spent LIBs will result in environmental pollution. Recycling practices are highly desirable at present and in the future from the point of view of environmental conservation ${ }^{7}$ and the recovery of metal values from spent LIBs and their utilization as raw materials ${ }^{8}$, in order to construct a sustainable and recyclingoriented society 9 . Then, it is relevant the development of batteries recovering and recycling methods. In case recovery and recycling are not possible, the environmental contamination by cumulative metals may affect the nervous system by lithium accumulation in the organism while the cobalt causes the "cobalt itch" (allergic contact dermatitis), in addition to conjunctivitis, lung lesions, asthma and bronchitis, hematologic and intestinal disturbances, cardiac effects and may also be carcinogen ${ }^{10}$. It is possible to recover cobalt in the following processes: hydrometallurgical, pyrometallurgical and electrochemical obtainment. The premise for the reprocessing of the cathodic material and the obtainment of lamellar double hydroxides (LDHs) is based on the fact that it can be made of the leaching 
followed by precipitation. The lamellar double hydroxides (LDHs) or hydrocalcite-type compounds are synthetic anionic clays which present structure identical to the brucite layers $\left(\mathrm{Mg}(\mathrm{OH})_{2}\right)$ but with a slight load difference on the lamellae. The precipitation method with constant $\mathrm{pH}$ is one of the most used methods to obtain the various types of LDHs and generally presents highly satisfactory results, obtaining LDHs with excellent structural organization and high purity of phase ${ }^{11}$. Thus, this paper's main objective was the establishment of a new cobalt and aluminum recovering methodology from the solution resulting from the chemical process of acid leaching followed by precipitation of the metals ( $\mathrm{Co}$ and $\mathrm{Al}$ ) for obtainment of the lamellar double hydroxide Co-Al-Cl.

\section{Materials and Methods}

\subsection{Synthesis of the Co-Al-Cl LDH pattern}

This synthesis method consists in the slow addiction of an aqueous solution containing $1.0 \mathrm{~mol} \mathrm{~L}^{-1} \mathrm{CoCl}_{2} \cdot 6 \mathrm{H}_{2} \mathrm{O}$ and $0.5 \mathrm{~mol} \mathrm{~L}^{-1}$ anhydrous $\mathrm{AlCl}_{3}$. Another solution containing 1.0 mol L ${ }^{-1} \mathrm{NaCl}$ and $3.5 \mathrm{~mol} \mathrm{~L}^{-1} \mathrm{KOH}$ was added to maintain the constant $\mathrm{pH}$ around of 8 . The suspension obtained was washed with deionized water and it was subjected to a hydrothermal treatment (HT) for $100 \mathrm{~h}$ at $80{ }^{\circ} \mathrm{C}$. After treatment, the suspension was filtered and the solid washed with deionized water at $\mathrm{pH} 8$ and subsequently it washed with alcohol and acetone. After washing, the material was dried under a vacuum for $48 \mathrm{~h}$ at room temperature.

\subsection{Synthesis of the Co-Al-Cl LDH from cathodic material reprocessing}

The Co-Al-Cl lamellar double hydroxide (LDH) was obtained by the cathodic material reprocessing method of lithium ion batteries (LIBs) from discarded cellular phones. The spent LIBs were submitted to physical treatment which involved a discharge pretreatment step to remove the excess capability, batteries dismantling to remove the plastic and metallic shells, scraping the cathode material, adapted from the methodology proposed by Dorella and Mansur ${ }^{12}$. First of all, it was realized the opening of the discharged batteries. The cathodic material $\left(\mathrm{LiCoO}_{2}\right.$, carbon black and binder) /current collector (aluminum foil) were separated of other elements of the battery as anode and electrolyte and reprocessed according to the following procedure steps:

i The leaching was conducted with $\mathrm{HCl}$ acid solution followed by the addition of a hydrogen peroxide solution;

ii Reaction system heating at $80^{\circ} \mathrm{C}$ for $4 \mathrm{~h}$ with stirring speed of $300 \mathrm{rpm}$;

iii Filtration of the leached solution for separation of carbon black and binder;

iv Dropwise addition of $3 \mathrm{~mol} \mathrm{~L}^{-1}$ hydroxide solution for $30 \pm 5$ min until the desired $\mathrm{pH}$;

v Partial evaporation of the solvent;

vi Filtration of the solid residue;

vii Hydrothermal treatment (HT) in the solid residue.

In step (i), the aluminum foil and lithium cobalt oxide $\left(\mathrm{LiCoO}_{2}\right)$ were ground together in order to recover the metals which are essential for the synthesis of LDH.
- sample (1) - $1 \mathrm{~g}$ of the cathodic material $\left(\mathrm{LiCoO}_{2}\right.$ and aluminum mixture) was lixiviated with $\mathrm{HCl} /$ $\mathrm{H}_{2} \mathrm{O}_{2}$. Subsequently, the LDH was obtained by coprecipitation at variable $\mathrm{pHs}$. The $\mathrm{pH}$ of the lixiviated solution was reached by addition of $3 \mathrm{~mol} \mathrm{~L}^{-1}$ lithium hydroxide $(\mathrm{LiOH})$ at $\mathrm{pH} 9$ or $\mathrm{pH} 11$ or ammonium hydroxide at $\mathrm{pH} 9\left(\mathrm{NH}_{4} \mathrm{OH}\right)$ as titrants. After the precipitation of the cobalt and aluminum hydroxide, the resulting solid residue (step iv) was filtered and washed with deionized water to remove any impurity in the system, and further dried. Then, the samples were structurally characterized by $\mathrm{X}$ ray diffraction analysis (XRD). Further, to the characterization, the solids were submitted to a hydrothermal treatment (HT), for $100 \mathrm{~h}$ at $70{ }^{\circ} \mathrm{C}$, in $1.5 \mathrm{~mol} \mathrm{~L}^{-1} \mathrm{NaCl}$ (step v). The samples were submitted again to the characterizations by XRD and TGA.

- sample (2) - The same process was carried out for the sample (2), using of $2 \mathrm{~g}$ total mass (1 $\mathrm{g}$ of $\mathrm{LiCoO}_{2}$ and aluminum mixture and the other $1 \mathrm{~g}$ only of aluminum foil) so that the oxide was previously scraped. Subsequently, it was varied the mass ratio between the aluminum and cobalt for obtaining of the Co-Al-Cl LDH.

\subsection{Characterizations of the synthesized materials}

\subsubsection{Structural characterization by $\mathrm{X}$-ray diffraction analysis (XRD)}

The powders were also characterized by X-ray diffraction analysis (XRD) using a Shimadzu model XRD $6000, \mathrm{Cu}-\mathrm{K} \alpha(\lambda=1,5418 \AA)$ radiation $(40 \mathrm{kV} 30 \mathrm{~mA})$ at $1^{\circ} \mathrm{min}^{-1}$. The speed step was $0.02^{\circ} \mathrm{s}^{-1}$ and a range of $5^{\circ} \leq 2 \theta \leq 70^{\circ}$. Samples are prepared from the sample powder, pressing the solid with a glass plate in aluminum sample port.

\subsubsection{Thermal characterization by Thermogravimetric analyses (TGA)}

The powders were characterized using a thermal analysis system Shimadzu DTG-60H simultaneous DTA-TG apparatus at $10{ }^{\circ} \mathrm{C} \mathrm{min}-1$ under $\mathrm{N}_{2}$ in a heating range from $25^{\circ} \mathrm{C}$ to $600{ }^{\circ} \mathrm{C}$. The reference sample used was alumina.

\subsubsection{Morphological characterization by Scanning Electron Microscopy (SEM)}

The SEM were recorded using a scanning electron microscope (SEM) Shimadzu SSX-550 Super Scan, operated at $10 \mathrm{kV}$. Samples were supported on the door sample by dispersing the powder over the silver conductive paste, since the samples did not show sufficient conductivity to generate good images.

\section{Results and Discussion}

The X-ray diffractograms of the LDH obtained from the solution resulting from the chemical process of acid leaching followed by precipitation of the metals (Co and $\mathrm{Al}$ ) in $\mathrm{LiOH}$ at $\mathrm{pH} 9$ and 11 are shown in Figures 1 and 2, respectively, and in $\mathrm{NH}_{4} \mathrm{OH}$ at $\mathrm{pH} 9$ is shown in 


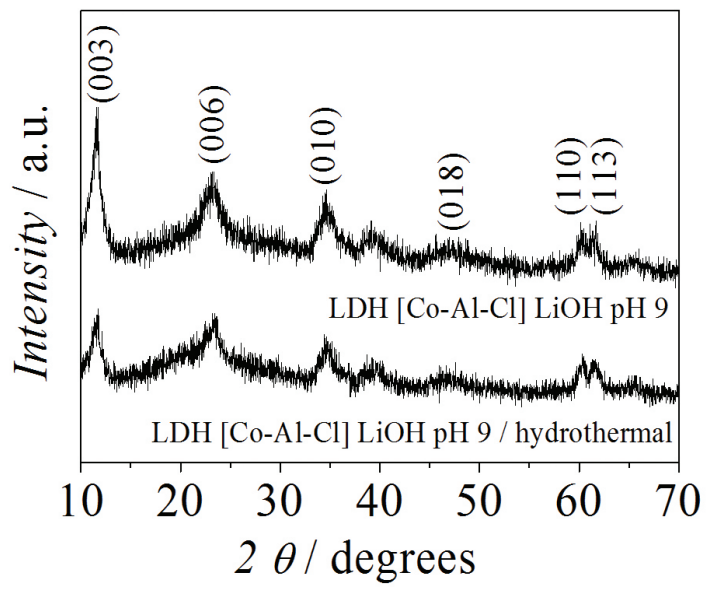

a)

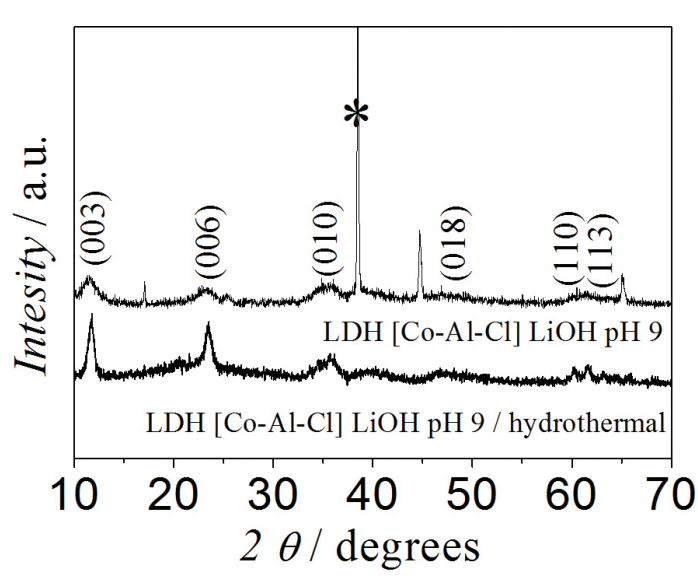

b)

Figure 1. X ray difractograms of the obtained LDHs by co-precipitation in LiOH at pH 9: (a) sample 1; (b) sample 2.

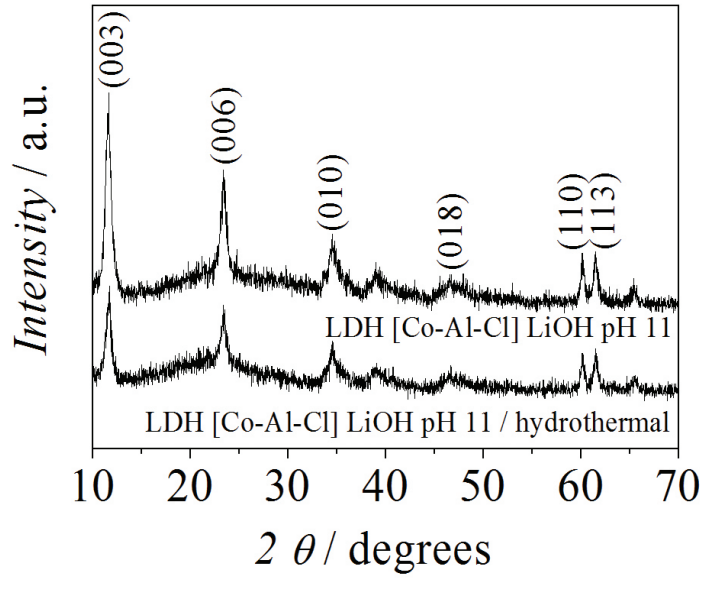

a)

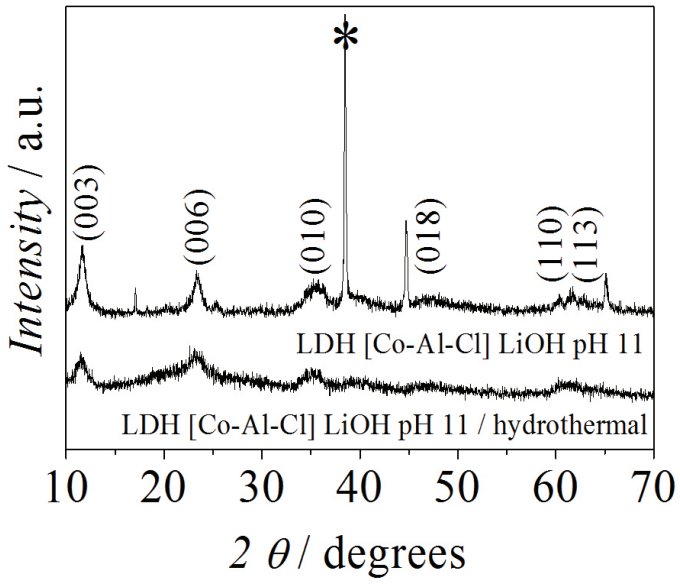

b)

Figure 2. $\mathrm{X}$ ray difractograms of the obtained LDHs by co-precipitation in LiOH at pH 11: (a) sample 1; (b) sample 2.

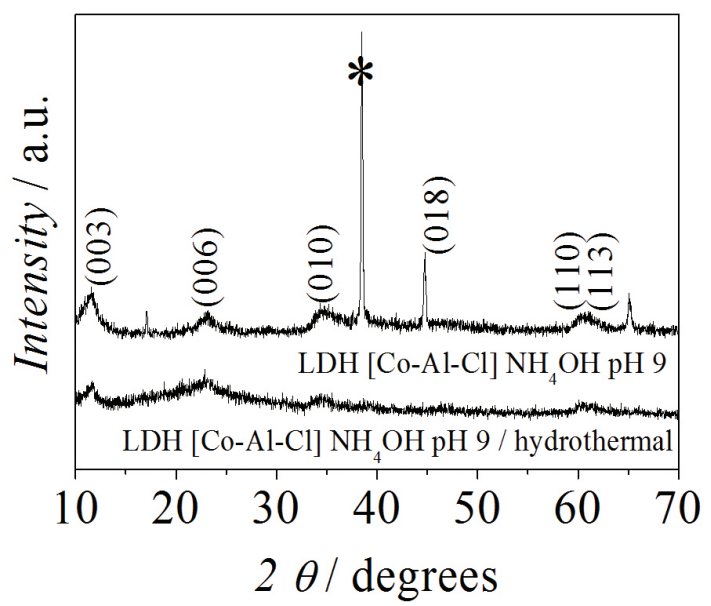

a)

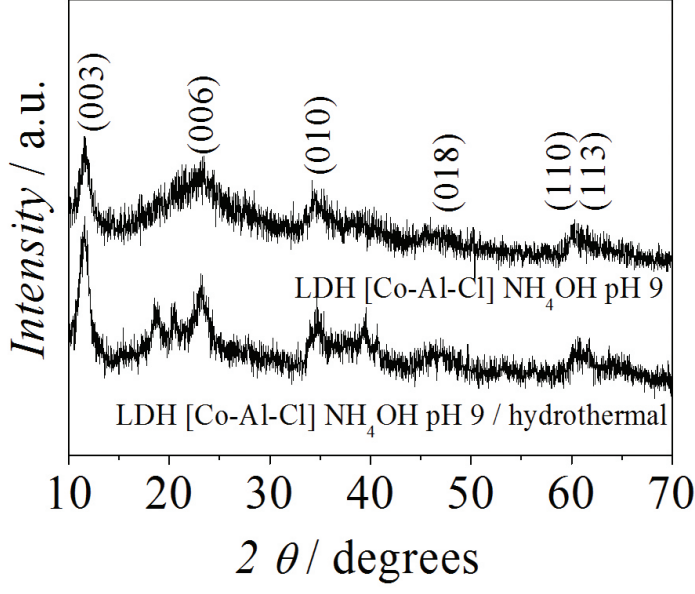

b)

Figure 3. X ray difractograms of the obtained LDHs by co-precipitation in $\mathrm{NH} 4 \mathrm{OH}$ at $\mathrm{pH}$ 9: (a) sample 1; (b) sample 2. 
Figure 3. The diffractograms of the samples containing a high concentration of aluminum called sample $\mathbf{2}$ - it was precipitated at $\mathrm{pH} 9$ and $11 \mathrm{using} \mathrm{LiOH}$. The XRD of this sample a diffraction peak at $2 \theta=38^{\circ}$ degree which is not relative to the characteristic lamellar structure of the $\mathrm{LDH}$ and it have been caused by the residual $\mathrm{NaCl}$ in the $\mathrm{LDH}$. Sample (1) obtained with $\mathrm{NH}_{4} \mathrm{OH}$ at $\mathrm{pH} 9$ did not show characteristic diffraction peak of the LDH even with the lowest amount of aluminum used in relation to the others.

Sample (1) at pH 9 and 11 using $\mathrm{LiOH}$ and sample (2) at $\mathrm{pH} 9$ using $\mathrm{NH}_{4} \mathrm{OH}$ did not present well defined diffraction peaks, which can infer that there was no influence of the amount of aluminum present in the probable LDHs obtained. Subsequently, the LDHs were subjected to a hydrothermal treatment in order to obtain a structure more orderly and without the mixture of phases. Then, $\mathrm{LDH}$ suspension was put in a reactor containing $1.5 \mathrm{~mol} \mathrm{~L}-1 \mathrm{NaCl}$ at $70{ }^{\circ} \mathrm{C}$ for $100 \mathrm{~h}^{[13,14]} \mathrm{X}$ ray diffractograms of the $\mathrm{LDH}$ obtained by precipitation in $\mathrm{LiOH}$ at $\mathrm{pH} 9$ after hydrothermal treatment (HT) presented a better definition of the diffraction peaks correspondent to the planes: 003, 006 and 110 (Figure 1b). In the XRD of the Figure 4 it observes among the synthesized LDH from the cathodic material those obtained by precipitation at $\mathrm{pH} 11$ with $\mathrm{LiOH}$ presented structure similar to the synthesized Co-Al-Cl LDH by the co-precipitation method at constant $\mathrm{pH} 8$ (LDH pattern $)^{15}$. The synthesized LDH by the method described in this paper

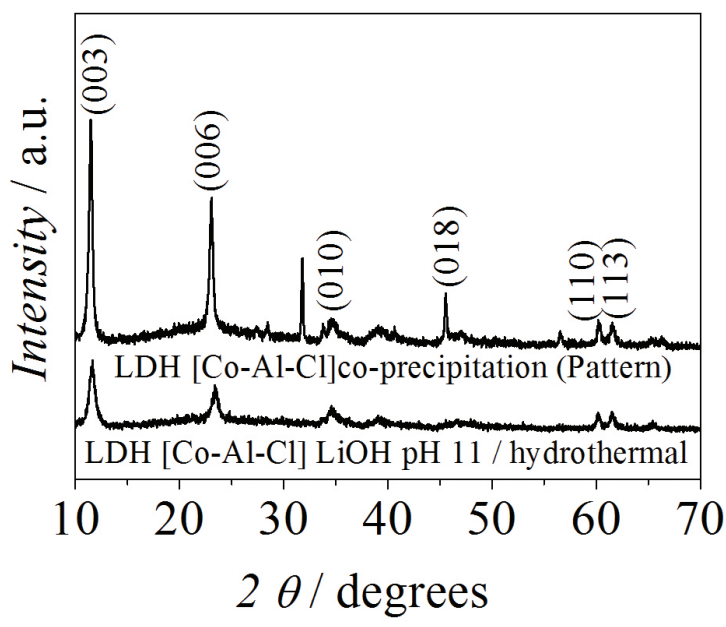

Figure 4. $\mathrm{X}$ ray difractograms of the obtained LDHs by co-precipitation in $\mathrm{LiOH}$ at $\mathrm{pH} 11$ / hydrothermal treatment (reprocessing method) and co- precipitation at $\mathrm{pH} 8$ (pattern). presented diffraction peaks centered at $11.66^{\circ}, 23.38^{\circ}$, $34.56^{\circ}, 46.66^{\circ}$ and $60.16^{\circ}$ which correspond to reflections 003, 006, 010, 018 and 110 according to the literature ${ }^{16,17}$. The basal spacing values - d (003), the distance between cations (a) and the unit cell height (c) were calculated using a Peakfit software, version 4, and are shown in the Table 1. It was observed in this Table that the highest diffraction peak correspondent to the plan 003 represents the $\mathbf{d}$ value relative to the sum of the lamellae thickness and the interlamellar region height, and may range between 7.6 and $7.8 \AA$, depending on the degree of hydration of the material ${ }^{16-18}$. Hydrocalcite parameter corresponds to the unit cell height, whereas parameter $\mathbf{a}$ is attributed to the distance between the cations on the calcite-type layer. Thus, the synthesized LDH in this paper presented the parameter $\mathbf{d}$ within the theoretical parameter and it is similar to that attributed to the hydrocalcite $(2.9942 \AA)$. In addition, the diffraction peak intensity rate corresponding to the plan 003 (7.55752 $\AA$ ) is approximately the double of plan 006 (3.79694 ̊). Then, the synthesized $\mathrm{LDH}$ in this paper presents the parameter $\mathrm{d}$ within the theoretical parameter and it is similar to that obtained for the Co-Al-Cl LDH pattern obtained from co-precipitation at $\mathrm{pH} 8$. As the diffraction peaks of the Co-Al-Cl LDH obtained by the precipitation with $\mathrm{LiOH}$ at $\mathrm{pH} 11$ were similar to the pattern, then this route was established as main LDH synthesis. The LDH followed by hydrothermal treatment was submitted for the thermal and morphological characterizations by thermogravimetry (TGA) and SEM, respectively.

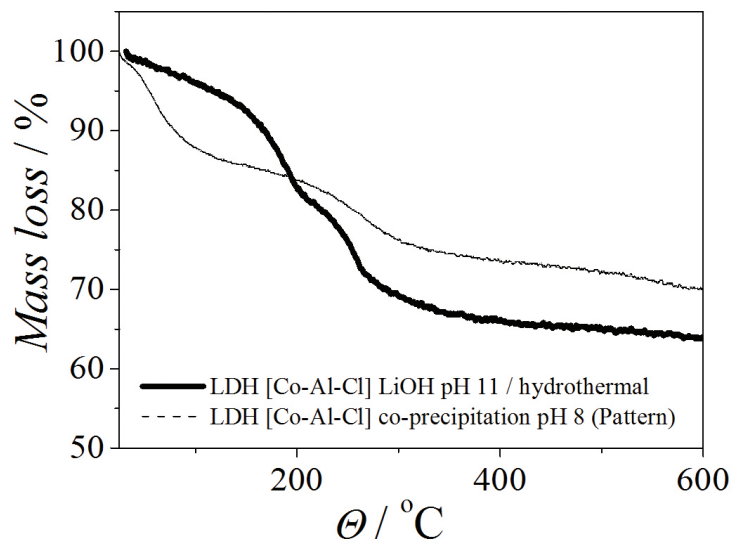

Figure 5. Thermogravimetric curves of the obtained LDHs by co-precipitation in $\mathrm{LiOH}$ at $\mathrm{pH} 11 /$ hydrothermal treatment (reprocessing method) and co- precipitation at $\mathrm{pH} 8$ (pattern).

Table 1. Basal spacing values of the obtained LDHs by co-precipitation in $\mathrm{LiOH}$ at $\mathrm{pH} 8$ (pattern) and by co-precipitation in $\mathrm{LiOH}$ at $\mathrm{pH}$ 11 / hydrothermal treatment (reprocessing method).

\begin{tabular}{ccc}
\hline Unit Cell parameter & $\begin{array}{c}\text { LDH [Co-Al-Cl] } \\
\text { co-precipitation at pH 8 (pattern) }\end{array}$ & $\begin{array}{c}\text { LDH [Co-Al-Cl] } \\
\text { LiOH at pH 11 (reprocessing) }\end{array}$ \\
\hline $\begin{array}{c}\mathbf{d} / \AA \\
\mathbf{d}(\mathbf{0 0 3}) \\
\mathbf{a} / \AA\end{array}$ & 7.6885 & 7.55752 \\
$\mathbf{2} \times \mathbf{d}(\mathbf{1 1 0})$ & 3.1556 & 3.14786 \\
$\mathbf{c} / \AA$ & & 23.43959 \\
$\mathbf{C =} \mathbf{3} \times \mathbf{d}(\mathbf{0 0 3})$ & 23.5752 & \\
\hline
\end{tabular}


Table 2. Variance analysis by TGA of the co-precipitation in $\mathrm{LiOH}$ at $\mathrm{pH} 8$ (pattern) and by co-precipitation in $\mathrm{LiOH}$ at $\mathrm{pH} 11 /$ hydrothermal treatment (reprocessing method).

\begin{tabular}{|c|c|c|c|c|}
\hline $\begin{array}{l}\text { Temperature } \\
\text { Range } /{ }^{\circ} \mathbf{C}\end{array}$ & Mass Loss events & $\begin{array}{c}\text { Mass Loss LDH co-precipitation } \\
\text { at pH } 8 \text { (pattern)/ }(\%)\end{array}$ & $\begin{array}{l}\text { Mass Loss LDH precipitation in } \\
\text { LiOH at pH } 11 \text { (reprocessing) (\%) }\end{array}$ & Variance \\
\hline $25.5-100$ & Extrisic Water & 12.09 & 3.94 & 4.075 \\
\hline 100-195 & Intrinsic Water & 3.70 & 13.51 & 4.905 \\
\hline 195-310 & Lamellae Dehydroxylation & 8.60 & 13.89 & 2.645 \\
\hline $500-600$ & Hydroxyl Decomposition & 2.10 & 1.13 & 0.485 \\
\hline$>600$ & Formation of Mixed Oxide & 30.21 & 37.54 & 3.665 \\
\hline
\end{tabular}

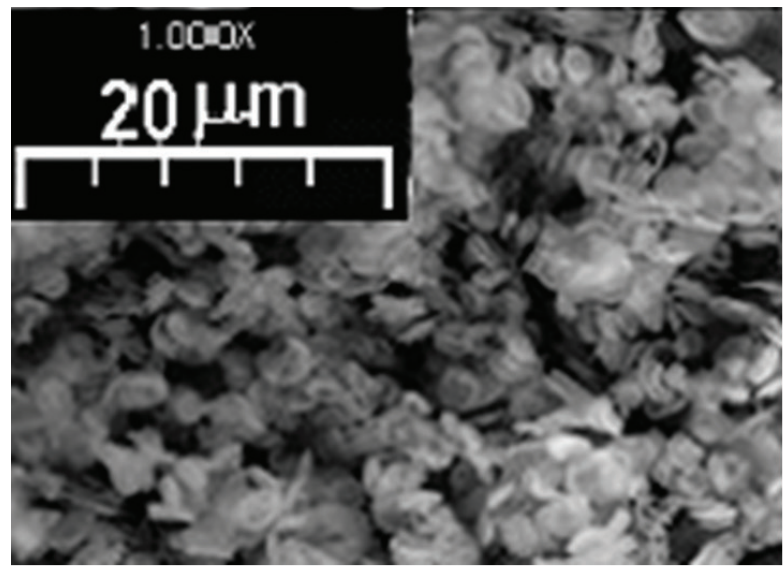

(a)

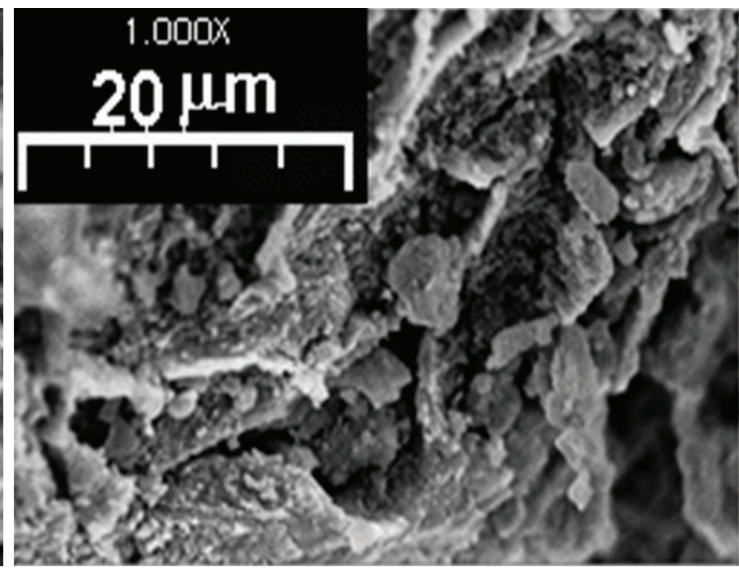

(b)

Figure 6. SEM of the obtained LDHs by (a) co-precipitation in LiOH at pH 11/ hydrothermal treatment (reprocessing method); (b) coprecipitation at $\mathrm{pH} 8$ (pattern).

In the Figure 5 is shown TGA of the obtained Co-Al$\mathrm{Cl} \mathrm{LDH}$ by co-precipitation at $\mathrm{pH} 8$ (constant $\mathrm{pH}$ method), used as pattern and the obtained $\mathrm{Co}-\mathrm{Al}-\mathrm{Cl} \mathrm{LDH}$ from the precipitation with $\mathrm{LiOH}$ at $\mathrm{pH} 11$. It was observed the respective mass loss: the first from $25.5^{\circ} \mathrm{C}$ to approximately $100{ }^{\circ} \mathrm{C}$, corresponding to a mass loss of $12.09 \%$ associated to the elimination of water adsorbed in the material. The second mass loss of $3.70 \%$ occurs from $100{ }^{\circ} \mathrm{C}$ to $190{ }^{\circ} \mathrm{C}$ is attributed to the interlamellar water loss. The final decomposition phase from $195{ }^{\circ} \mathrm{C}$ to $310^{\circ} \mathrm{C}$ with a mass loss of $8.6 \%$ associated to the dihydroxylation of the $\mathrm{LDH}$ lamellae and finally from $500{ }^{\circ} \mathrm{C}$ to $600{ }^{\circ} \mathrm{C}$, a mass loss of $2.1 \%$ related to the remaining part of the hydroxyl decomposition and formed of a Co and Al mixed oxide, corresponding to the $30.21 \%$ of the initial mass. The TGA for the obtained LDH by the reprocessing of the lithium ion battery cathodic material. It was observed the first $3.94 \%$ mass loss from $25.5^{\circ} \mathrm{C}$ to approximately $100^{\circ} \mathrm{C}$, correspondent to the adsorbed water elimination in the material structure. The mass loss second (13.51\%) from $100{ }^{\circ} \mathrm{C}$ to $195^{\circ} \mathrm{C}$ is associated to the loss of the interlamellar water correspondent to the solvated anions. The final decomposition phase from $195^{\circ} \mathrm{C}$ to $310^{\circ} \mathrm{C}$ with a mass loss of $13.89 \%$ is associated to the $\mathrm{LDH}$ lamellae dihydroxylation. Finally from $500{ }^{\circ} \mathrm{C}$ to $600{ }^{\circ} \mathrm{C}$, there is a mass loss of $1.13 \%$ related to the remaining part of the hydroxyl decomposition. From $600{ }^{\circ} \mathrm{C}$ there is a constant residual mass attributed to the formation of the $\mathrm{Co}$ and $\mathrm{Al}$ mixed oxide, corresponding to the $37.54 \%$ of the initial mass. All TGA results are summarized in the Table 2.

SEM of the LDH obtained by co-precipitation at $\mathrm{pH} 8$ (pattern) (Figure 6a) with 1000 times amplification presented superimposed inorganic boards and with a hexagonal shape, such results were similar to the morphologies obtained for LDH by the co-precipitation method ${ }^{18}$. Figure $6 \mathrm{~b}$ shows SEM of the LDH obtained by reprocessing cathodic material from lithium ion batteries (with $\mathrm{LiOH}$ at $\mathrm{pH} 11$ after hydrothermal treatment). It was observed an irregular shape of the LDH, with high porosity and some clustering. This morphology was similar to those obtained by Reis et al. for $\mathrm{Mg}-\mathrm{Al}-\mathrm{CO}_{3} \mathrm{LDH}^{[19]}$.

These materials will test as adsorbents of pesticides and herbicides in contaminated waters ${ }^{20}$.

\section{Conclusions}

The $\mathrm{X}$ ray diffractograms of the sample obtained by the coprecipitation with $\mathrm{LiOH}$ at $\mathrm{pH} 11$ / hydrothermal treatment showed diffraction peaks similar to the $\mathrm{Co}-\mathrm{Al}-\mathrm{Cl}$ LDH pattern.

From the TGA data of the Co-Al-Cl LDH obtained by reprocessing method it was verified four (4) mass loss characteristics events of the thermal decomposition of the LDH. 
From the SEM of the Co-Al-Cl LDH, it was possible to observe an irregular shape of the $\mathrm{LDH}$, with high porosity and some clustering. Thus, the synthesized LDH by reprocessing method presented structural, thermal and morphological characteristics similar to the Co-Al-Cl LDHLDH pattern obtained at $\mathrm{pH} 8$, becoming possible its application as adsorbent of pesticides and herbicides in contaminated waters.

The Co-Al-Cl LDH obtained by precipitation with $\mathrm{LiOH}$ at $\mathrm{pH} 11$ / hydrothermal treatment showed structural,

\section{References}

1. Lupi C, Pasquali M and Dell'era A. Nickel and cobalt recycling from lithium-ion batteries by electrochemical processes. Waste Manag. 2005; 25(2):215-220. http://dx.doi.org/10.1016/j. wasman.2004.12.012

2. Castillo S, Ansart F, Laberty-Robert C and Portal J. Advances in the recovering of spent lithium battery compounds. Journal Power Sources. 2002; 112:247-254. http://dx.doi.org/10.1016/ S0378-7753(02)00361-0

3. Salgado AL, Veloso AMO, Pereira DD, Gontijo GS, Salum A and Mansur MB. Recovery of zinc and manganese from spent alkaline batteries by liquid-liquid extraction with Cyanex 272 . Journal Power Sources. 2003; 115(2):367-373. http://dx.doi. org/10.1016/S0378-7753(03)00025-9

4. Bernardes AM, Espinosa DCR and Tenório JAS. Recycling of batteries: a review of current processes and technologies. Journal Power Sources. 2004; 130(1-2):291-298. http://dx.doi. org/10.1016/j.jpowsour.2003.12.026

5. Paulino JF, Busnardo NG and Afonso JC. Recovery of valuable elements from spent Li-batteries. Journal of Hazard Materials. 2008; 150(3):843-849. http://dx.doi.org/10.1016/j. jhazmat.2007.10.048

6. Ramos LJ. Lítio. Available from: <http://www.dnpm.gov. br/assets/galeriaDocumento/SumarioMineral2008/litio.pdf>. Access in: 21/05/2013.

7. Pranolo Y, Zhang $\mathrm{W}$ and Cheng CY. Recovery of metals from spent lithium-ion battery leach solutions with a mixed solvent extractant system. Hydrometallurgy. 2010; 102(1-4):37-42. http://dx.doi.org/10.1016/j.hydromet.2010.01.007

8. Zhong H, Li J and Chai L. Rare Earth Metal Hard Alloy. 2001. 144 p.

9. Chang TC, You SJ, Yu BS and Yao KF. A material flow of lithium batteries in Taiwan. Journal Hazardous Materials. 2009; 163(2-3):910-915. http://dx.doi.org/10.1016/j. jhazmat.2008.07.043

10. Reider NMVL and Gunther WMR. Impactos Ambientais e Sanitários causados por descarte inadequado de pilhas e baterias usadas. Revista Limpeza Pública. 2003; 60:20-26.

11. De Roy A, Forano C, El Malki K and Besse JP. Layered Double Hyddroxides Present and Future. New York: Nova Science Publishers; 2001. p. 1-100. morphological and thermal characteristics similar to the pattern Co-Al-Cl LDH obtained by co-precipitation at constant $\mathrm{pH} 8$.

\section{Acknowledgements}

This work was supported by FAPEMIG (grants APQ 2279/10) and REDE MINEIRA DE QUÍMICA.

12. Dorella G and Mansur MB. A study of the separation of cobalt from spent Li-ion battery residues. Journal of Power Sources. 2007; 170(1):210-215. http://dx.doi.org/10.1016/j. jpowsour.2007.04.025

13. Tronto J, Crepaldi EL, Pavan PC, De Paula CC and Valim JB. Organic anions of pharmaceutical interest intercalated in magnesium aluminum LDHs by two different methods. Molecular Crystals and Liquid Crystals. 2001; 356(1):227237. http://dx.doi.org/10.1080/10587250108023703

14. Velu S, Suzuki K, Okasaki M, Osaki T, Tomura S and Ohashi F. Synthesis of new SN incorporated layered double hydroxides and their evolution to mixed oxides. Materials Research Bulletin. 1999; 34(10):1707-1717. http://dx.doi.org/10.1016/ S0025-5408(99)00168-3

15. Hyppólito MP, Freitas LL, Amaral FA and Canobre SC. Influência do Método de Síntese do HDL nas propriedades do Compósito de HDL/Ppi. In: Anais 34 Reunião Anual da Sociedade Brasileira de Química; 2011; Florianópolis. Florianópolis: Editora SBQ; 2011. p. 60.

16. Del Arco M, Fernándes A, Martín C and Rives C. Intercalation of mefenamic and meclofenamic acid anions in hydrotalcitelike matrixes. Applied Clay Science. 2007; 36(1-3):133-140. http://dx.doi.org/10.1016/j.clay.2006.04.011

17. Arai Y and Ogawa M. Preparation of Co-Al layered double hydroxides by the hydrothermal urea method for controlled particle size. Applied Clay Science. 2009; 42(3-4):601-604. http://dx.doi.org/10.1016/j.clay.2008.04.011

18. Leroux F, Gachon J and Besse JP. Biopolymer immobilization during the crystalline growth of layered double hydroxide. Journal of Solid State Chemistry. 2004; 177(1):245-250. http:// dx.doi.org/10.1016/j.jssc.2003.08.013

19. Reis MJ, Silvério F, Tronto J and Valim JB. Effects of $\mathrm{pH}$, temperature and ionic strength on adsorption of dodecylbenzenesulfonate into $\mathrm{Mg} / \mathrm{Al}-\mathrm{CO}_{3}$ layered double hydroxides. Journal of Physics and Chemistry of Solids. 2004; 65: 487-492. http://dx.doi.org/10.1016/j. jpcs.2003.09.020

20. Freitas LL, Fagundes WS, Coelho MG, Amaral FA and Canobre SC. Síntese e Caracterização do Compósito de PAni/ PDMcT/HDL e sua aplicação como adsorvente de pesticida. In: Anais do $20^{\circ}$ Congresso Brasileiro de Engenharia e Ciência dos Materiais; 2012; Joinville. Joinville: Editora CBECIMAT, 2012. p. 4371. 